\title{
The Sacred Road: A Contribution to the History of Ramesvaram Pilgrimages
}

\author{
Jean Deloche* \\ Ecole Francaise D’Extreme - Orient, 10 Dumas Street Pondicherry-605001
}

(Received 30 November 2018)

\begin{abstract}
Pilgrims going to Ramesvaram via the railway line above the Pamban Pass do not know that, in the olden days, there was, covering a distance of 8 miles, a magnificent paved avenue, across the island to the holy shrine. Called the "Sacred Road" by the Dutch, it has been described by travellers at the beginning of the 19th century, but identified only recently. The glory of this religious artery has vanished long ago, but vestiges of the old way made of a double line of hewn stones and edged with monuments can still be seen. It is believed that these two parallel stone strips were intended for the wheels of the temple car which was brought from Ramesvaram across the reef to the continent until the 15th century. But it is obvious that the main purpose of this work was also to facilitate the access to the celebrated temple, as it was used by thousands of pilgrims every year. The multiplicity and diversity of the constructions during this era shows that the 18th century which, throughout India, was a period of political decline, was, for the Ramesvaram pilgrimage, a kind of golden age.
\end{abstract}

Key words: Load rests, Pavement, Pilgrimage, Ramesvaram, Rest houses, Road, Wells.

\section{Introduction}

Vestiges of ancient roadways are still in evidence in many regions of India. Some have been discovered and studied by archaeologists, many have not yet attracted learned attention. Around or within certain of the religiously significant towns, streets and roads were sometimes paved to facilitate the access to these precincts for

\footnotetext{
DOI: $10.16943 / \mathrm{ijhs} / 2019 / \mathrm{v54i3/49747}$

*Email: jeandeloche@gmail.com

'This paper is revised version of translation of an article published in French in 1985 entitled: Etudes sur la circulation en Inde, V, Le chenal de Pampan et la route de pèlerinage de Ramesvaram: un exemple d'aménagement ancien, BEFEO, t. LXXIV, 1985, pp. 167-182, $\mathrm{X}$ plts. This revised edition has made use of this opportunity to correct errors or omissions and to incorporate new material, particularly Dutch sources which shed new light on the subject.
}

pilgrims. In the Karnul district for example, near the celebrated centre of pilgrimage of Srisailam, the remains of a road paved with enormous stone blocks along a distance of at least $13 \mathrm{~km}$ were found (Deloche, 1993, pp. 101103). But the most singular paved road leading to the most revered shrine of South India and used by thousands of visitors every year, was built between Pamban and Ramesvaram. It has been described in details by travellers at the beginning of the 19th century.

\section{Evidence}

In January 1804, when the English traveller Valentia covered the distance between Ramesvaram and Pamban, he was surprised at finding that "the road was paved all the way, which had been done at different times by holy and 
affluent men" and that "nearly every hundred yards there was a choultry and an attendant brāhmin" (Valentia, 1809, p. 343). In February of the same year, another Englishman, Reverend James Cordiner, following the same path, was impressed by its exceptional facilities.

The road to Pombon (Pamban) is most elegantly paved all the way with smooth stones, each six feet in length and four feet broad, and the greater part of it is nobly shaded by the most beautiful and majestic trees which India produces... All the large trees in this superb avenue are surrounded with smooth terraces of masonry raised several feet from the ground on which travellers rest in comfort completely sheltered from the rays of the sun... At the end of almost every mile stands an excellent choultry or ambalam, containing various open apartments formed of stone pillars and back walls with adjoining courts, in which are rooms where travellers may lodge in great privacy... and, at the distance of every furlong, are erected either two square pillars of single stones with one placed horizontally across them, or an oblong stone intended as places where loaded travellers may rest their burden and likewise to display inscriptions in the Malabar language, recording the names and specifying the donations of persons who have contributed to the support of those religious and charitable institutions... The highly finished temples, the majestic trees, the extensive pavements and the comforts contrived for travellers rendered this journey one of the most singular and interesting which it has been our lot to perform. (Cordiner, 1807, pp. 273-274, 281).

This road, called the "SACRED ROAD" by the Dutch (Bes, 1997, p. 77) is clearly shown in the Atlas of the Southern part of India, circa 1850 (Figure 1).

And yet, such a rare technological realization had not been identified. It is not mentioned in any reports of the Archaeological Survey of India or of the State Department of Archaeology. Fortuitously stretches of the old path were discovered at the time of a visit to Ramesvaram in February 1983, when our auto-rikshaw to whom the question was put told us that we were standing on it and accepted to take us to Pamban and show its vestiges (once

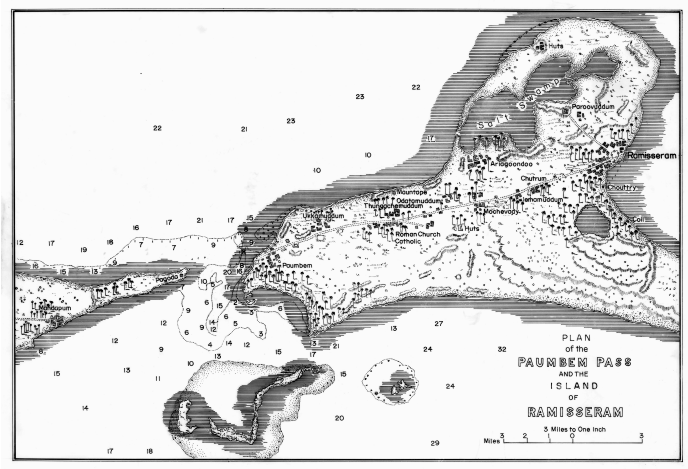

Figure 1 Ramesvaram Island (Atlas of the Southern Part of India, circa. 1850).

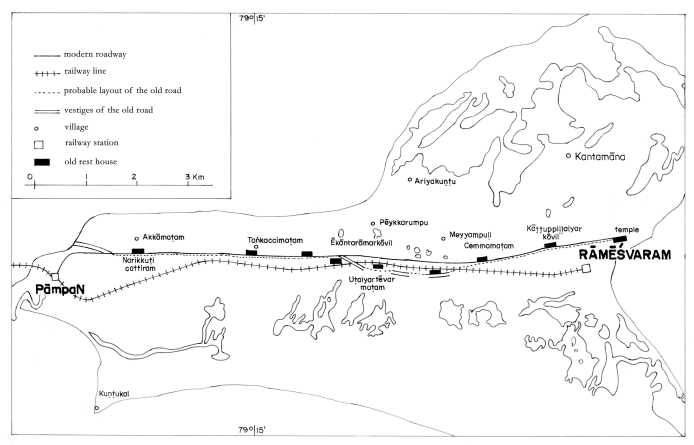

Figure 2 Vestiges of the old Road from Ramesvaram to Pamban.

again here is good example of collective memory!). We visited the site again in February 1984.

The glory of this religious artery has vanished long ago. Today, only some parts of the pavement are found; the large avenue of trees does not exist anymore and most of the constructions are in a bad condition: all the religious and charitable institutions have disappeared.

\section{Vestiges of the old roadways}

The modern tarred road is built on the old one. It is lined, on both sides, with vestiges of rest houses (cattiram), load rests (cumaitanki) and water reservoirs ( $k u$ lam). The main feature of the old path is a double line of hewn stones. The gap which separates the two rows consists of a gravelled path of calcareous material whose dimensions vary from 3.40 to $3.60 \mathrm{~m}$. The slabs are large 
coral sandstone blocks (found in plenty near Pamban), rectangular in shape, $80-90 \mathrm{~cm}$ long, $40-60 \mathrm{~cm}$ broad, and arranged alternately (Figure 3).

Of this path four sections can be seen today. The first one, at Meyyampuli, to the south of the railway line, spreads over 500 metres; midway it is lined, to the right, with an abandoned cattiram and, to the left, with a cumaitanki (Figure 4). Then, it disappears under a sand dune and reappears 500 metres further, before being buried beneath another sand dune (Figure 5). It is again seen to the west of the completely ruined site of Udaiyardevarmadam where it crosses the railway line and reaches the modern road near Ekantaramarkovil (Figure 6 \& Figure 7). Finally, it reappears just before reaching the reef to the north of Pamban, near the road bridge (Figure 8).

James Cordiner also says (1807, p. 280), that to the north of the temple of Ramesvaram there was a two miles long road, "partly paved with flat stones, and shaded by large trees, in a style corresponding with the avenue formerly mentioned." It is shown in the Atlas of Southern part of India, leading to Paruvatham (Figure 1 ), but we could not find any remains of this pavement.

\section{Vestiges of monuments}

The numerous substructures erected along the road are probably the ruins of the buildings mentioned by James Cordiner. The best preserved are: (i) At $1.5 \mathrm{~km}$ from the temple of Ramesvaram, the rest-house flanking the Kattuppilaiyarkovil, square in shape, is lined with a gallery with columns. It comprises a veranda in front and an open courtyard inside (Figure 9). (ii) $1.4 \mathrm{~km}$ further, to the west of Semmamadam is another rest-house of the same type with a well, still used today (Figure 10 \& Figure 11). (iii) Near Meyyanpuli, there is a ruined cattiram (Figure 12). (iv) $2.8 \mathrm{~km}$ to the west, at Ekantaramarkovil, is a well built mandapa but in danger of falling down (Figure 13). (v) At $1 \mathrm{~km}$ east of Tangachimadam stands a large rest-house, square in shape, consisting of a gallery with a raised square platform, provided with a well and surrounded with a wall (Figure 14, Figure 15 \& Figure 16). (vi) In the centre of Tangachimadam, there is a similar but smaller construction, also provided with a wall (Figure 17). (vii) $2 \mathrm{~km}$ to the west, at Akkamadam, the Narikkuti cattiram, originally surrounded with a wall today almost destroyed, is partly buried beneath a sand dune (Figure 18). Nearby, there is a stone well, rectangular in shape with a flight of steps. (viii) On reaching Pamban, between the old pavement and the modern road, we find a large kulam today used by the villagers (Figure 19) and a cattiram (Figure 20) also surrounded with a wall.

This enclosure found in most of the rest-houses-also mentioned in Dutch sources (Bes, 1997, p. 77) is typical of the island of Ramesvaram. It shows that people were mainly concerned about security.

\section{When and why was the road built?}

What do we know about this unusual work? From the outset it should be noted that this road is not an ordinary path, i.e. a long narrow stretch with a paved surface, but a double line of cut stones, consisting of two parallel strips set at fixed distance apart. Obviously, it was designed for vehicles with a $4 \mathrm{~m}$. long axle. Only large processional temple chariots are provided with such shaft on which wheels rotate. The road was therefore mainly intended for a temple car.

Now, two traditions are available regarding its creation:

1. According to the first one, the road was built at the beginning of the 18th century and is attached to a tragic anecdote (Vanamalai Pillai, 1929, p. 40-41; Ramaswami, 1972, p. 91, 971). The Setupati Vijaya Ragunatha (1711-1725) appointed his son-in law to the command of Pamban port with the explicit order that he should assist the pilgrims in their passage over the channel. Instead of complying with the order, the latter levied a trifling boat fee from all the passengers and with this poll tax he is supposed to have paved the eight miles of sandy road between Pamban and Ramesvaram with a parallel row of hard stone. The Setupati, enraged by this disobedience put him to death against the pleadings of his two daughters who committed sati with their husband. Their memory is preserved in the two rest-houses built of the road: Akka (elder sister) matam and Tankacci (younger sister) matam.

This story is touchingly naïve, but can't be accepted. At that time, the path was already in existence. The Dutch who had temporarily occupied the island in 1690 specifically mention that there was no other road as the large and dense thorn-bushes made the island otherwise virtually impassable to them (Bes, 1997, p. 77). 


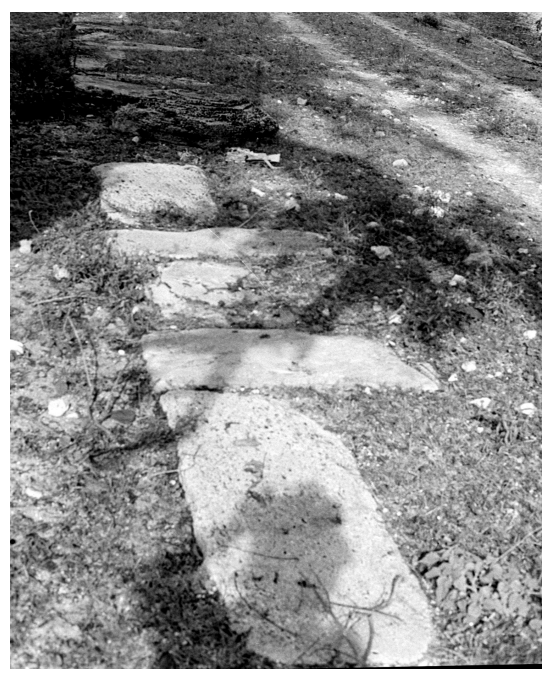

Figure 3 Meyyampuli: coral sandstone slabs.

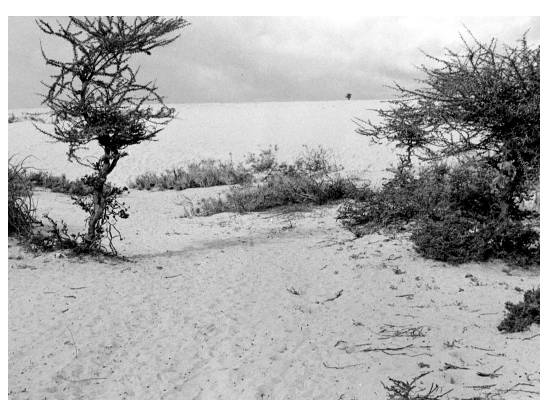

Figure 5 Sand dune on the roadway.

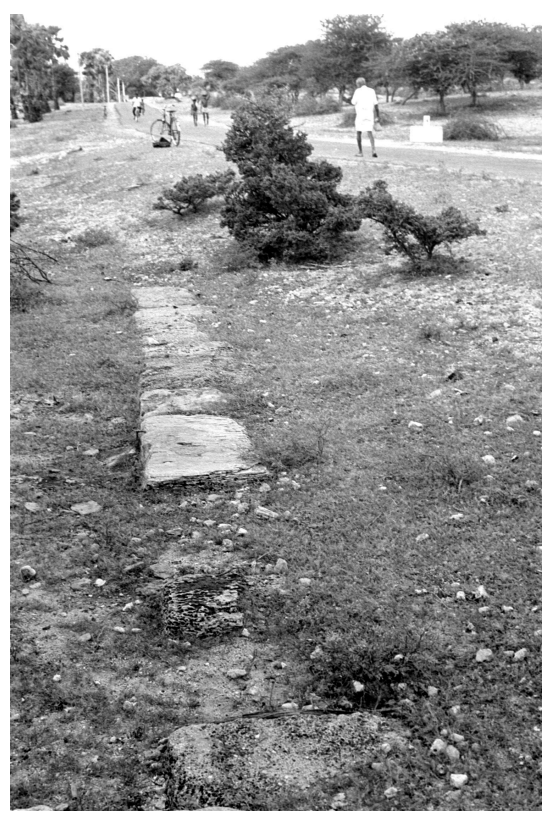

Figure 7 Id.: meeting point of the two roads.

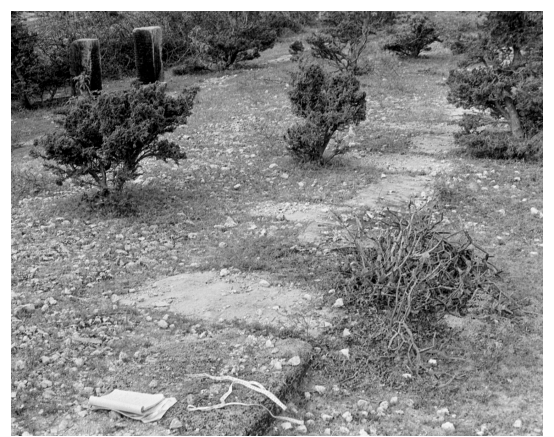

Figure 4 Meyyampuli: the old pavement.

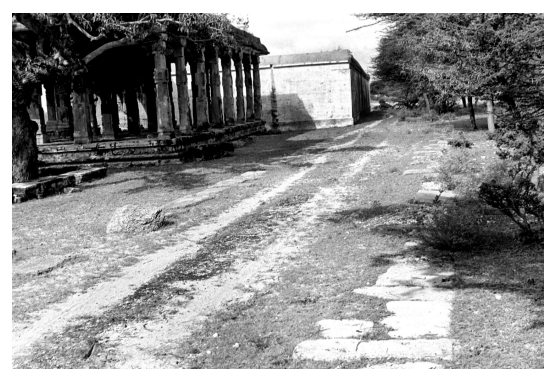

Figure 6 Ekantaramarkovil: the old and the new roads.

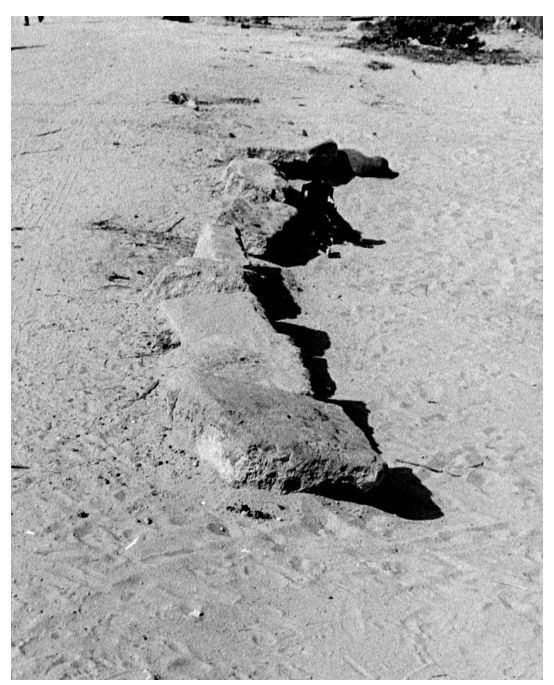

Figure 8 Pamban: the last slabs before reaching the sea. 


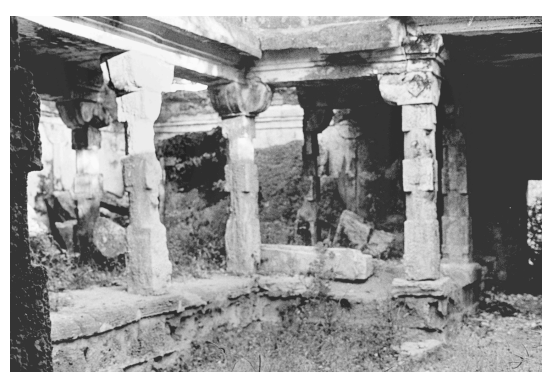

Figure 9 Kattuppilaiyarkovil: the cattiram.

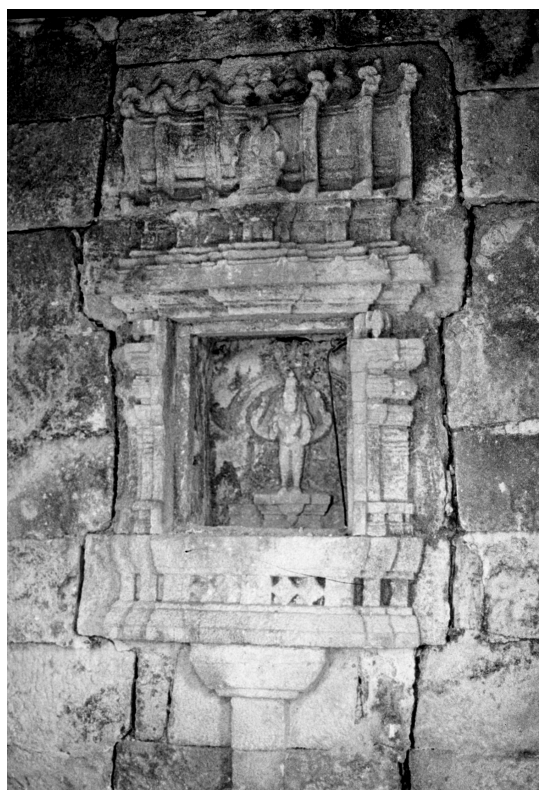

Figure 11 Id.: inside the cattiram.

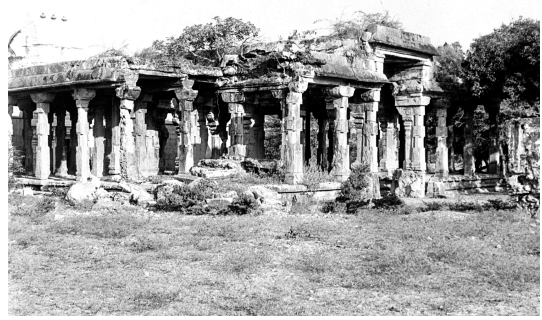

Figure 13 Ekantaramarkovil: mandapa near the temple.

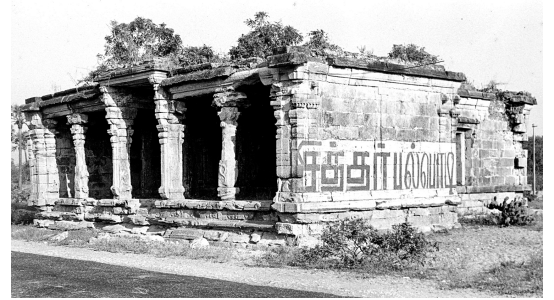

Figure 10 Semmamadam: the cattiram.

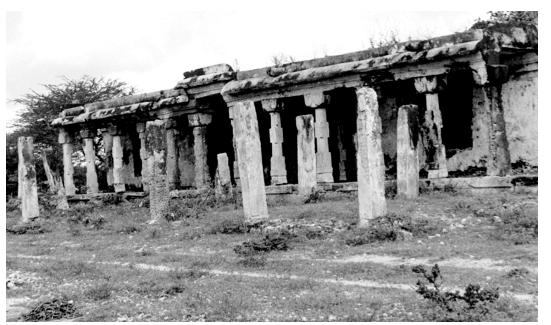

Figure 12 Meyyampuli: abandoned cattiram.

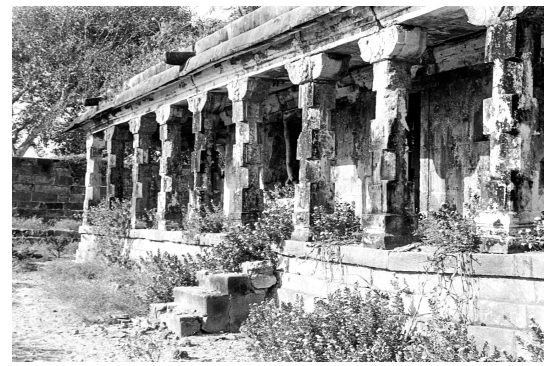

Figure 14 One km east of Tangachimadam: the cattiram. 


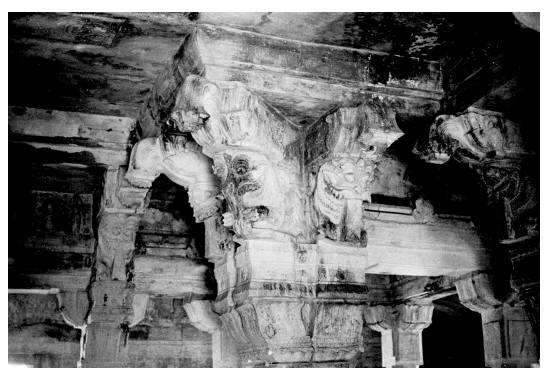

Figure $15 I d$.: inside the cattiram.

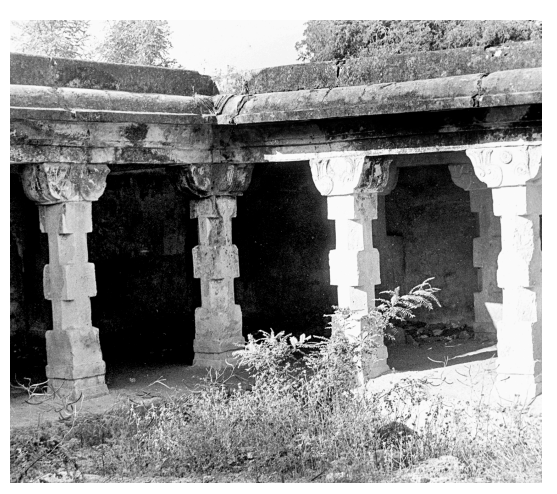

Figure 17 Tangachimadam: the cattiram.

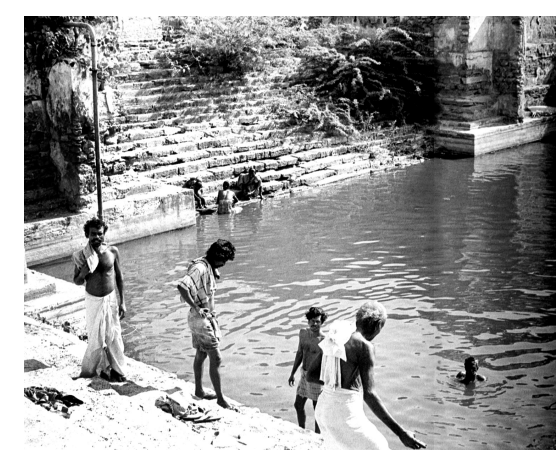

Figure 19 Pamban: to the north, the large kulam.

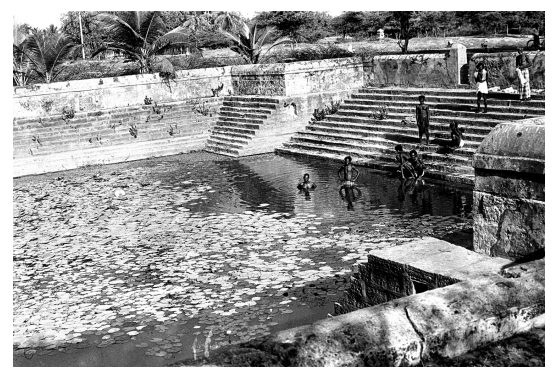

Figure 16 Id.: the kulam.

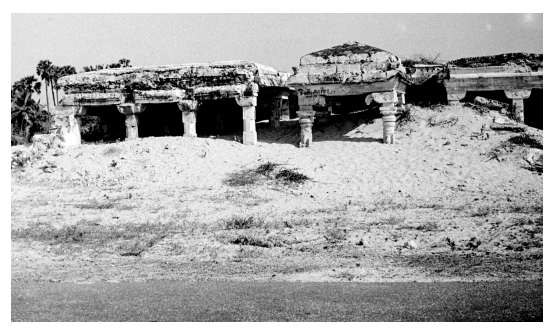

Figure 18 Akkamadam: Narikkutti cattiram.

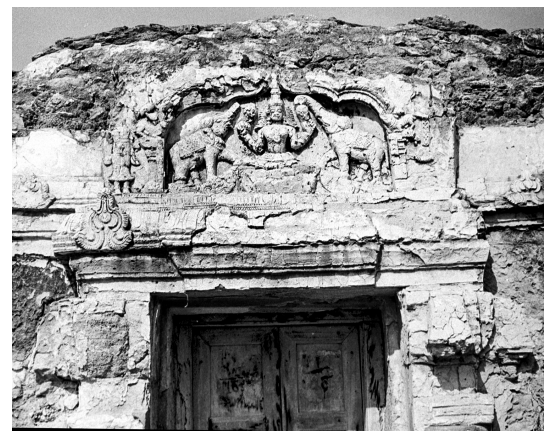

Figure 20 Pamban, id.: entrance to the cattiram. 
2. According to the second tradition, until the end of the 15th century, the Ramesvaram temple car was drawn at the time of festivals by thousands of men with the help of thick coir from the holy city towards the main land. Sim (1834, pp. 10-11) mentions that, at that time, "the sammy of Ramisseram was carried across the main land three times every year on particular festivals." M. Philips who was years in the neighbourhood refers to the same explanation since he mentions that "the double line of cut stones along the road from Pamban to Ramesvaram was intended, I supposed, for the wheels of the idol-car which, was brought in old days across the reef to the main land" (Manuci, 1907, vol. IV, p. 449).

3. This implies that the Pamban Pass did not exist, that there was no channel between the island and the peninsula. In fact, various documents tend to prove that the separation of the island has been ascribed to a big cataclysm at the end of the 15th century.

It seems that the present breach is of recent origin, that the island of Ramesvaram was linked to the peninsula by an isthmus which was broken by a series of storms. According to records of the Ramesvaram temple, until the early part of the 15th century, the island was connected with the continent by a narrow neck of land or causeway, but, in 1480, a violent storm breached the isthmus and, though the opening was filled up and repaired, subsequent hurricanes rendered the breach permanent (Sim, 1834, pp. 10-11; Thornton, 1854, p. 101; Maclean, 1893, p. 666). The local traditions too testify to this phenomena. An administrative document, dated 1826, regarding families doing pilot work in the Pamban Pass, confirms the supposition: "they said that, about 250 years ago, the Pamban Pass was not so broad and the people used to walk across it; then a hurricane struck it and it was broadened so much that neither people nor vessels could cross it (Tamilnadu Archives, vol. III, p. 196)". Bruce Foot, the archaeologist, believes that Ceylan was connected with the main land "in times late enough to come within the perview of tradition" the rupture of communication has been less due to subsidence than to the breaching of the causeway by the waves in 1480 CE (Ramaswami, 1972, p. 456).

Obviously the road ended at Mandapam, the gate- way to the southern peninsula, named after a stone mandapa built on the southern coast to which Ramanathasvami from Ramesvaram was brought and taken back annually.

4. Assuming this explanation to be consistent, it can be said: (a) that the two rows of hewn stones were already built at the end of the 15th century and that, when the peninsula was still linked to the continent, the Ramesvaram temple car was pulled to the main land, and (b) that the graveled path could have been repaired in the gap by the unfortunate son-in-law of the Setupati.

The first explanation is based only on traditions collected by European observers. However it is surprising that such an extraordinary achievement is not mentioned in any Tamil or Sanskrit sources. The second explanation is plausible: it has been said above that the island was strewn with the thorns of the babul and that it was safe for the barefooted pilgrims to follow the old road, i.e. to keep to the beaten track.

5. There is still a big question to which we found no answer. We still do not know why the Ramesvaram ter could be brought and taken back for such a long distance three times a year. Usually, in South India, the temple cars are drawn at the time of festival through the streets around the temple only. They function as mobile temples. In Ramesvaram, the temple is busy with puja and festivals throughout the year. Among the latter three important ones are performed and draw people from far off places. Moreover, the island has about forty tirtha or sacred water bath places. One of them is found at Tangachimadam, the other one at Ekantamarkovil, on the old path (Sethuraman, 2013, pp. 160-167).

We have seen supra that there was a similar path made of a double line of hewn stones leading to a smaller temple, may be a tirtha, two miles north of the main shrine. Was it used for processions?

According to James Cordiner (1807, pp. 272273 \& 279-280), in 1804, there were "five swamy coaches used for the purpose of carrying the idols in procession laid up on the sides of the east street." But regarding long distance processions we have no information. 


\section{Conclusion}

All things considered, it can be said that the old path was unique in the subcontinent. In India all roads lead to Ramesvaram. As far as Mandapam, at the extremity of the main land, pilgrims coming from the north could make their way as they liked, select their paths according to their devotion or whims. These arteries, connected by smaller veins formed a veritable circulatory system through which flowed all the religious life of the Tamil country. But after reaching Pamban all these branches were linked to the main stem. There was only one trunk, one way. Of all the routes of the peninsula it was the best provided with a tree lined avenue, rest houses, shelters of all kinds, load rests.

This foundation, reflecting the traditional Hindu organization of pilgrim routes endured without great damage the upheavals of history. The military campaigns of the Mughals in the South, the Franco-English wars scarcely affected them. The religious circulation did not slacken. Consider how many princes and wealthy individuals constructed houses for pilgrims during the period, when fortresses and trading posts were under siege. The multiplicity and diversity of these establishments during the era shows that the eighteen century, which, throughout India, was a period of political decline, was for the Ramesvaram pilgrimage a kind of golden age.

\section{Bibliography}

[1] An Atlas of the southern part of India, including plans of all the principal towns \& cantonments, reduced from the grand trigonometrical survey of India, shewing also the Tenasserim provinces, Pharoah \& Co., Madras, 1854.

[2] Bes, L. Friendship as long as the Sun and Moon Shine, Ramnad and its Perception of the Dutch East India Company, 1725-1750, Leiden, 1997, p. 77.

[3] Cordiner, J. A Description of Ceylon containing an Account of the Country, Inhabitants and Natural productions, with Narratives of a Tour round the Island in 1800, the Campaign in Candy in 1803 and a Journey to Ramisseram in 1804, illustrated by 25 engravings from original drawings, London, 1807, reprint Dehiwala, 1983.
[4] Deloche, J. Transport and Communications in India prior to Steam Locomotion, J. Walker (Tr.), Oxford University Press, New Delhi, vol. I, Land Transport, 1993, pp. 101-103.

[5] Deloche, J. Etudes sur la circulation en Inde, V, Le chenal de Pampan et la route de pèlerinage de Ramesvaram: un exemple d'aménagement ancien, BEFEO, $\mathrm{t}$. LXXIV, 1985, pp. 167-182, X pls.

[6] Maclean, C. D. (Ed.), Manual of the Administration of the Madras Presidency, Vol. III, Glossary, Madras, 1893, reprint, Asian Educational Services, New Delhi, 1982.

[7] Manuci, N. Storia do Mogor, Irwine, W (Ed.), London, 1907-8, Vol. IV, p. 449.

[8] Ramaswami, A. Tamilnadu District Gazetteers Ramanathapuram, Madras, 1972, pp. 91, 971.

[9] Sethuraman, G. The Saiva Temple of India: A Study on Rameswaram Temple, Sharada Publishing House, Delhi, 2013.

[10] Sim, Major, Journal of the Royal Geographical Society, London, Vol. IV, 1834.

[11] Tamilnadu Archives, Guide to Records of Madura District, 1790-1835, Vol. III.

[12] Thornton, E. A Gazetteer of the Territories under the Government of the East-India Company, W. H. Allen \& Company, London, 1854.

[13] Valentia, G. Voyages and Travels to India, the Red Sea, Abyssinia and Egypt in the Years 1802, 1803, 1804 and 1806, London, 1809.

[14] Vanamalai Pillai, N. The Setu and Ramesvaram, Madras, 1929. 